\title{
Screening of Six Parents and 15 Cross Combinations against Bacterial Wilt (Ralstonia solanacearum)
}

\author{
Quamruzzaman AKM ${ }^{1 *}$, Nahar MS ${ }^{2}$ and Chowdhury MAZ ${ }^{3}$ \\ ${ }^{1}$ Division of Olericulture, Horticulture Research Centre, Bangladesh Agricultural Research Institute, Bangladesh \\ ${ }^{2}$ Plant Pathology Section, Horticulture Research Centre, Bangladesh Agricultural Research Institute, Bangladesh \\ ${ }^{3}$ Bangladesh Agricultural Research Council, Bangladesh
}

Submission: April 19, 2019; Published: May 06, 2019

"Corresponding author: Quamruzzaman AKM, Olericulture Division, Horticulture Research Centre, Bangladesh Agricultural Research Institute, Gazipur, Bangladesh

\begin{abstract}
The study on the screening for resistance to bacterial wilt (Ralstonia solanacearum) of six parents and 15 cross combinations/hybrids were evaluated under artificial epiphytotic conditions at the Plant Pathology lab and glass house of Plant Pathology Section of Horticulture Research Centre (HRC) of Bangladesh Agricultural Research Institute (BAIR), Gazipur, Bangladesh during the period from September 2016-17 to develop high yielding $\mathrm{F}_{1}$ eggplant varieties resistant to bacterial wilt. Amongst the six parents and 15 hybrids, six hybrids viz., $\mathrm{F}_{1} 4 \times 17, \mathrm{~F}_{1} 4 \times 5, \mathrm{~F}_{1} 18 \times 17$, $\mathrm{F}_{1} 3 \times 17, \mathrm{~F}_{1} 3 \times 5, \mathrm{~F}_{1} 17 \times 5$ showed resistant $(\mathrm{R})$ reaction. The cross $\mathrm{F}_{1} 3 \times 17, \mathrm{~F}_{1} 17 \times 5$ exhibited the lowest percent of wilt $(10 \%)$ followed by $\mathrm{F}_{1}$ $4 \times 17(16.67 \%), \mathrm{F}_{1} 3 \times 5$ (13.33 \%). In case of parents, three parents showed resistant (R) reaction viz. BL083 (20.00\% wilting), BL081 (16.67\% wilting) and BLS2 (16.67\% wilting). Incubation period ranges from 4 days to 12 days. The lowest incubation period (4 days) was observed form the parent BL034 followed by Islampuri ( 5 days) and Uttara ( 6 days), hybrids $\mathrm{F}_{1} 4 \times 14$ ( 6 days) and $\mathrm{F}_{1} 18 \times 14$ ( 6 days).
\end{abstract}

Keywords: Ralstonia solanacearum; Hybrids; Epiphytotic; Plant Pathology; Horticulture

Abbreviations: HRC: Horticulture Research Centre; BAIR: Bangladesh Agricultural Research Institute; TZC: Triphenyl Tetrazolium Chloride; CRD: Completely Randomized Design; HR: Highly Resistant; MR: Moderately Resistant; MS: Moderately Susceptible; HS: Highly Susceptible

\section{Introduction}

Bacterial wilt caused by Ralstonia solanacearum [1], synonym Pseudomonas solanacearum Smith (1914), is widespread in the tropical, subtropical and temperate region, where it represents a major constraint to the production of numerous crops [2,3]. Recent reviews showed the very extensive host range of $R$. solanacearum which includes several hundred species representing about 53 families of plants [4]. Host species include ornamentals, weeds and important crops such as tomato (Lycopersicum esculentum L.) potato (Sonalum tuberosum L.) eggplant (Solanum melongena L.), chilli pepper (Capsicum spp.), tobacco (Nicotiana tabacum L.), ginger (Zingiber officinale L.), peanut (Arachis hypogea L.) etc.

The incidence of soil borne diseases particularly bacterial wilt caused by Ralstonia solanacearum E.F. Sm. is the most limiting factor to produce eggplant in Bangladesh. Not only in Bangladesh, bacterial wilt is a disease of world wide importance in eggplant production [5]. An early crop of eggplant is very profitable for the farmers in Bangladesh, but the early crop is particularly vulnerable to this disease. Once the eggplants are affected by bacterial wilt, they die within three to four days. The organism when injected in the susceptible hosts through the root systems cause vascular wilt and ultimate death of the plant [6]. The characteristics symptoms of bacterial wilt in most hosts are wilting, stunting and yellowing of the foliage. With susceptible infected eggplants, the most striking symptom is the rapid and complete wilting of the plants following field infection. Distinct epinasty of the petioles prior to wilting may be apparent if disease development is slow. Internal symptoms include discoloration of vascular tissue and decay of portions of the pith at the advanced stages of infection. It is the most destructive bacterial plant pathogen especially in the warm regions [6]. In recent years, bacterial wilt has become a great problem for eggplant cultivation in Bangladesh. The main effort to control this disease has been directed towards the development of resistance cultivars. But available information suggests that very few of the cultivars were reported as resistant to this disease. Various attempts to control bacterial wilt of different crops have 
been reported [7] but success was limited. Breeding for resistance, therefore, remains the best control strategy, even though varietal resistance differs in different localities due to extreme variability and adaptation of the pathogen [8].

The grafting of cultivated variety on wild brinjal root-stock can successfully control the disease [9], but grafting technology is not well adopted to the farmers due to some technological aspects and it is some time troublesome. So, development of disease resistant cultivar is the easiest way to solve the problem, but development of disease resistant variety is not easy. Many workers are still working in the world to develop disease resistant variety. The development of resistant cultivars for the control of bacterial wilt has been successful in the case of tobacco and peanut [3]. Many cultivars of tomato are resistant for certain environments, but their resistance was not stable under conditions of high temperature and humidity in the lowland tropics. Similarly, some chilli accessions which were found to be resistant in India were susceptible in Japan [10]. Thus, the development of resistant variety in specific locations of the crops to certain pathogen remained a continuous process. Available information suggests that no appreciable attempt has yet been made to study the local as well as the available exotic plant material against bacterial wilt resistance in Bangladesh. Besides, no hybrid variety has been screened against bacterial wilt disease. The present study has been undertaken to evaluate the performance of the hybrid variety against bacterial wilt disease.

\section{Materials and Methods}

The present study was carried out to find out the resistance against bacterial wilt of the 15 cross combinations/hybrids and six parents and screened them to find out suitable cross combination of inbred lines for developing hybrid variety with high yield and wilting resistant. The materials required and methodology are described below under the following sub-heading.

\section{Experimental site}

The present experiment was conducted at the Plant Pathology lab and glass house of Plant Pathology Section of Horticulture Research Centre (HRC) of Bangladesh Agricultural Research Institute (BAIR), Gazipur, Bangladesh during the period from September 2016-17.

Materials: Six parents and 15 cross combinations/hybrids total 21 eggplant genotypes were used in this experiment. The parents were selected not only based on high yield and other yield contributing characters and quality but also on the basis bacterial wilt resistant. Therefore, the selected parents exhibited some degrees of resistant and the main objective of the experiment was to find out how the intensity of resistance turns to the hybrids form the parents.

Seeding production: Seeds of the parents and cross combinations were sown in steel tray containing sterilized soils mixture (soil: sand: compost) in the ratio of $3: 2: 1$ on $1^{\text {st }}$ September 2016. Before sowing, the seeds were treated with $\mathrm{GA}_{3}$ solution (100ppm) for 24 hours at room temperature for quick and uniform germination. Seedlings were germinated on trays with sterilized soils mixture for a period of ten days. Ten days after seed germination young seedlings were transferred to the individual plastic pot $(9 \mathrm{~cm}$ diameter) containing sterilized soil mixed with $50 \%$ organic matter $(\mathrm{v} / \mathrm{v})$.

Bacterial cultures, preparation of inoculum and stock cultures: Pure culture of $R$. solanacearum strain used in this study was isolated form wilted eggplant showing typical symptoms of bacterial wilt form the research field of Plant Pathology Section, HRC, BARI. The pathogen on isolation on triphenyl tetrazolium chloride (TZC) agar medium [6] yielded grayish white, fluidal colonies with light pink centers. After purification, the isolate was characterized as race 1 according to pathogenicity and host range [2], and biochemical test [4]. The identification of the isolates was also confirmed by Cock's Postulate. All isolates were kept as stock culture in lyophilized form and in $5 \mathrm{ml}$ sterilized tap water kept at $15{ }^{\circ} \mathrm{C}$. Before preparation of inoculum, the bacteria was streaked on TZC from the stock culture. The inoculum was prepared by culturing the virulent and fluidal colony of $R$. solanacearum on casamino acid-peptone-glucose (CPG) agar medium.

\section{Experimental design}

The plants of 15 cross combinations and six parents were arranged in the glass house following Completely Randomized Design (CRD) with three replications and ten plants were inoculated in each replication. Line to line and plant to plant distance were maintained $30 \mathrm{~cm}$ and $25 \mathrm{~cm}$ respectively. The plants were inoculated when they were approximately 35 days old (15 days after transplanting in plastic pot).

Inoculation: Suspension of $R$. solanacearum was prepared form the stock culture which was grown on CPG for 48 hours at $300 \mathrm{C}$. A sterile toothpick was used to inoculate the bacterial suspension containing approximately $2.0 \times 108 \mathrm{cfu} / \mathrm{ml}$ (colony forming unit per milliliter) was inserted at the axil of $3^{\text {rd }}$ fully expanded leaf of the plants. Plants were observed regularly for the initiation of symptoms of wilt, incubation period, $25 \%$ and $50 \%$ plant wilt (days after inoculation). After recording the $50 \%$ wilted plant data regularly, data recorded at seven days interval and final data recorded at 42 days after inoculation. The initiation of the first wilt-symptoms after inoculation and the number of wilted plants for each accession was recorded and graded on a 0-5 rating scale of Winstead \& Kelman [5] with some modifications. The modified rating scale is;

$0=$ Plants did not show any symptoms of wilt; highly resistant (HR)

$$
\begin{aligned}
& 1=1-20 \% \text { plants wilted; resistant }(\mathrm{R}) \\
& 2=21-40 \% \text { plants wilted; moderately resistant (MR) } \\
& 3=41-60 \% \text { plants wilted; moderately susceptible (MS) } \\
& 4=61-80 \% \text { plants wilted; susceptible (S) }
\end{aligned}
$$


$5=$ more than $80 \%$ plants wilted; highly susceptible (HS)

The reaction of the hybrids and parents were categorized as highly resistant, resistant, moderately resistant, moderately susceptible to highly susceptible, depending on the percentage of wilt of the plants. The incubation period, time taken to produce $25 \%$ and $50 \%$ wilt at days after inoculation (DAI) were also recorded. Final data on wilting (recorded at $42 \mathrm{DAI}$ ) were converted into percent wilt and the reaction of the genotypes was graded on a 0-5 rating scale according to Winstead \& Kelman [5].

\section{Results and Discussion}

The reaction of the eggplant parents and hybrids against bacterial wilt shown in Table 1. It was revealed form the result reaction against bacterial wilt exhibited different degrees of variation. Among the 15 cross combinations, six hybrids showed resistant (R), seven hybrids showed moderately resistant (MR) and two hybrids showed moderately susceptible (MS) reaction against wilting. But in case of the parents three showed resistant (R) and three parents showed moderately susceptible (MS) reaction against wilting.

Table 1: Reaction of 15 hybrids combinations and six parents to Ralstonia solanacearum.

\begin{tabular}{|c|c|c|}
\hline Hybrids and Parents & $\%$ of Wilt & Reaction* \\
\hline $\mathrm{F}_{1} 4 \times 18$ & 40 & MR \\
\hline $\mathrm{F}_{1} 4 \times 3$ & 23.33 & MR \\
\hline $\mathrm{F}_{1} 4 \times 17$ & 16.67 & $\mathrm{R}$ \\
\hline $\mathrm{F}_{1} 4 \times 5$ & 20 & $\mathrm{R}$ \\
\hline $\mathrm{F}_{1} 4 \mathrm{x} 14$ & 43.33 & MS \\
\hline $\mathrm{F}_{1} 18 \mathrm{x} 3$ & 26.67 & MR \\
\hline $\mathrm{F}_{1} 18 \times 17$ & 20 & $\mathrm{R}$ \\
\hline$F_{1} 18 \times 5$ & 23.33 & MR \\
\hline $\mathrm{F}_{1} 18 \times 14$ & 46.67 & MS \\
\hline $\mathrm{F}_{1} 3 \times 17$ & 10 & $\mathrm{R}$ \\
\hline $\mathrm{F}_{1} 3 \times 5$ & 13.33 & $\mathrm{R}$ \\
\hline $\mathrm{F}_{1} 3 \times 14$ & 36.67 & MR \\
\hline $\mathrm{F}_{1} 17 \times 5$ & 10 & $\mathrm{R}$ \\
\hline $\mathrm{F}_{1} 17 \mathrm{x} 14$ & 26.67 & MR \\
\hline $\mathrm{F}_{1} 5 \times 14$ & 36.67 & MR \\
\hline Uttara (4) & 43.33 & MS \\
\hline Islampuri (18) & 46.67 & MS \\
\hline BL083 (3) & 20 & $\mathrm{R}$ \\
\hline BL081 (17) & 16.67 & $\mathrm{R}$ \\
\hline $\mathrm{BLS}_{2}(5)$ & 16.67 & $\mathrm{R}$ \\
\hline BL034 (14) & 56.67 & MS \\
\hline
\end{tabular}

N.B. $4=$ Uttara, $18=$ Islampuri, $3=$ BL083, $17=$ BL081, $5=$ BLS2, 14 $=\mathrm{BL} 034$

${ }^{*} 0$ = Plants did not show any symptoms of wilt, highly resistant (HR); $1=1-20 \%$ plants wilted, resistant $(R) ; 2=21-40 \%$ plants wilted, moderately resistant (MR); $3=41-60 \%$ plants wilted, moderately susceptible (MS); $4=61-80 \%$ plants wilted, susceptible (S); $5=$ more than $80 \%$ plants wilted; highly susceptible (HS).
Among the 15 hybrids six hybrids viz., $\mathrm{F}_{1} 4 \times 17, \mathrm{~F}_{1} 4 \times 5, \mathrm{~F}_{1} 18 \times 17$, $\mathrm{F}_{1} 3 \times 17, \mathrm{~F}_{1} 3 \times 5, \mathrm{~F}_{1} 17 \times 5$ showed resistant $(\mathrm{R})$ reaction. The cross $\mathrm{F}_{1}$ $3 \times 17, F_{1} 17 \times 5$ exhibited the lowest percent of wilt (10\%) followed by $\mathrm{F}_{1} 4 \times 17$ (16.67 \%), $\mathrm{F}_{1} 3 \times 5$ (13.33 \%). The $20.00 \%$ wilting was observed form hybrids $\mathrm{F}_{1} 4 \times 5, \mathrm{~F}_{1} 18 \times 17$. Seven hybrids showed moderately resistant (MR) reaction against bacterial wilt disease and the percent wilting plants ranged from 23.33 to $40.00 \%$. The hybrids exhibited $23.33 \%$ wilting were $\mathrm{F}_{1} 4 \mathrm{x} 3, \mathrm{~F}_{1} 18 \times 5 ; 26.67 \%$ wilting observed form the hybrids $\mathrm{F}_{1} 18 \times 3, \mathrm{~F}_{1} 17 \mathrm{x} 14 ; 36.67 \%$ form $\mathrm{F}_{1} 3 \times 14, \mathrm{~F}_{1} 5 \times 14$ and $40.00 \%$ from $\mathrm{F}_{1} 4 \times 18$. Moderately susceptible (MS) reaction showed only by two hybrids they were $\mathrm{F}_{1} 4 \times 14$ (43.33\% wilting) and $\mathrm{F}_{1} 18 \times 14$ (46.67\% wilting).

In case of parents, three parents showed resistant (R) reaction viz. BL083 (20.00\% wilting), BL081 (16.67\% wilting) and $\mathrm{BLS}_{2}(16.67 \%$ wilting). Three parents exhibited moderately susceptible (MS) reaction they were Uttara (43.33\% wilting), Islampuri (46.67\% wilting) and BL034 (56.67\% wilting). Rahman [9] reported from an experiment against bacterial wilt $(R$. solanacearum) that line BL081 showed resistant reaction while the genotypes BL099 showed moderately resistant reaction. Six genotype BL117, ISD011, ISD001, BLS18, BLS 2 and Tarapuri (hybrid variety) were found moderately susceptible to bacterial wilt.

From the above discussion it was revealed that the hybrids along with the parents BL083, BL081 and BLS 2 showed resistant to moderately resistant reaction against bacterial wilt and increased the resistant reaction against the disease intensity. All the hybrids performed better than the lower parent and mid parent and sometime better parent also. When the parent crossed with BL034 performance was not satisfactory. Among the 15 cross combinations the hybrids $\mathrm{F}_{1} 3 \times 17, \mathrm{~F}_{1} 17 \times 5, \mathrm{~F}_{1} 4 \times 17, \mathrm{~F}_{1} 3 \times 5, \mathrm{~F}_{1} 4 \times 5, \mathrm{~F} 1$ $18 \times 17$ performed better and showed resistant reaction (R; wilting $0-20 \%$ plant) than other hybrids against bacterial wilt disease. Rashid et al. screened twenty-three local and exotic cultivars of eggplant and three wild relatives of the crop against bacterial wilt in the glass house. The wild relatives Sonalum mammosum was found resistant while the cultivar Dingaras Multiple Purple and Khakhatia long were found moderately resistant, the cultivars Nayankazal, Kahkhatia round, Tiwan naga, Nagasaki naga and Kurume naga were found moderately susceptible, while the rest of the cultivars as highly susceptible to bacterial wilt.

Mochizuki \& Yamakawa [11] studied the resistant of selected eggplant cultivars and wild Solanum species to bacterial wilt. They reported that among eggplant cultivars tested "Dingras Multiple Purple" (from India) and "Aubergine" (form USA) showed higher resistant to bacterial wilt "Taiwan naga" one of the most resistant cultivars in Japan. Eggplant varieties No. 1 (from Malaysia) and "Sinampiro", "Makiling" and "Mayon" (form the Philippines) showed resistance like that of "Tiwan naga".

Incubation period ranges from 4 days to 12 days (Table 2). The lowest incubation period (4 days) was observed form the parent BL034 followed by Islampuri ( 5 days) and Uttara ( 6 days), hybrids 
$\mathrm{F}_{1} 4 \mathrm{x} 14$ ( 6 days) and $\mathrm{F}_{1} 18 \times 14$ ( 6 days). The highest days (12) for incubation was recorded for hybrids $\mathrm{F}_{1} 4 \times 17$ and $\mathrm{F}_{1} 17 \times 5$ followed by $\mathrm{F}_{1} 3 \times 17$ (11 days), parent BL081 (11 days). Form the discussion it was revealed that moderately susceptible genotypes required fewer days (4 to 6 days) and moderately resistant to resistant genotypes required more days (7 to 12 days) for incubation.

Table 2: Incubation period and \% wilt form DAl of 15 hybrids combinations and six parents to Ralstonia solanacearum.

\begin{tabular}{|c|c|c|c|}
\hline $\begin{array}{l}\text { Hybrids and } \\
\text { Parents }\end{array}$ & $\begin{array}{c}\text { Incubation } \\
\text { Period (days) }\end{array}$ & 25\% Wilt DAI* & $50 \%$ Wilt DAI* \\
\hline $\mathrm{F}_{1} 4 \times 18$ & 7 & 10 & - \\
\hline $\mathrm{F}_{1} 4 \times 3$ & 9 & - & - \\
\hline $\mathrm{F}_{1} 4 \times 17$ & 12 & - & - \\
\hline $\mathrm{F}_{1} 4 \times 5$ & 10 & - & - \\
\hline $\mathrm{F}_{1} 4 \mathrm{x} 14$ & 6 & 9 & - \\
\hline $\mathrm{F}_{1} 18 \mathrm{x} 3$ & 8 & - & - \\
\hline $\mathrm{F}_{1} 18 \times 17$ & 9 & - & - \\
\hline $\mathrm{F}_{1} 18 \mathrm{x} 5$ & 9 & - & - \\
\hline $\mathrm{F}_{1} 18 \mathrm{x} 14$ & 6 & 8 & - \\
\hline $\mathrm{F}_{1} 3 \times 17$ & 11 & - & - \\
\hline $\mathrm{F}_{1} 3 \times 5$ & 10 & - & - \\
\hline $\mathrm{F}_{1} 3 \times 14$ & 7 & 12 & - \\
\hline $\mathrm{F}_{1} 17 \mathrm{x} 5$ & 12 & - & - \\
\hline $\mathrm{F}_{1} 17 \mathrm{x} 14$ & 9 & - & - \\
\hline $\mathrm{F}_{1} 5 \times 14$ & 7 & 11 & - \\
\hline Uttara (4) & 6 & 9 & - \\
\hline Islampuri (18) & 5 & 7 & - \\
\hline BL083 (3) & 10 & - & - \\
\hline BL081 (17) & 11 & - & - \\
\hline $\mathrm{BLS}_{2}(5)$ & 10 & - & - \\
\hline BL034 (14) & 4 & 6 & 9 \\
\hline
\end{tabular}

N.B. $4=$ Uttara, $18=$ Islampuri, $3=$ BL083, $17=$ BL081, $5=$ BLS2, 14 $=$ BL034

${ }^{*} \mathrm{DAI}=$ Days after inoculation

Only parent BL034 exhibited 56.67\% wilting and days after incubation was nine days. The rest of the other resistant, moderately resistant and moderately susceptible genotypes did not show $50 \%$ wilt even at 42 days after inoculation. Among the 15 cross combinations 13 hybrids did not show $25 \%$ wilting and among the six parents three parent did not $25 \%$ wilting at final data collection (42 DAI). Six hybrids exhibited 25\% wilting within 8 to 12 days and three parents showed 25\% wilting within 6 to 11 days.

\section{Conclusion}

Pure culture of R. solanacearum strain used in this study was isolated form wilted eggplant showing typical symptoms of bacterial wilt form the research field. Considering the reaction to Ralstonia solanacearum the six parents and 15 hybrids, six hybrids viz., $F_{1} 4 \times 17, F_{1} 4 \times 5, F_{1} 18 \times 17, F_{1} 3 \times 17, F_{1} 3 \times 5, F_{1} 17 \times 5$ showed resistant $(\mathrm{R})$ reaction. The cross $\mathrm{F}_{1} 3 \times 17, \mathrm{~F}_{1} 17 \times 5$ exhibited the lowest percent of wilt (10\%) followed by $\mathrm{F}_{1} 4 \times 17$ (16.67\%), $\mathrm{F}_{1}$ $3 \times 5$ (13.33\%). In case of parents, three parents showed resistant (R) reaction viz. BL083 (20.00\% wilting), BL081 (16.67\% wilting) and $\mathrm{BLS}_{2}(16.67 \%$ wilting). Incubation period ranges from 4 days to 12 days (Table 2). The lowest incubation period (4 days) was observed form the parent BL034 followed by Islampuri (5 days) and Uttara ( 6 days), hybrids $\mathrm{F}_{1} 4 \times 14$ ( 6 days) and $\mathrm{F}_{1}$ 18x14 (6 days).

\section{References}

1. Yabuuchi E, Kosako Y, Yano I, Hotta H, Nishiuchi Y (1995) Transfer of two Burkholderia and an Alcaligenes species to Ralstonia gen. nov: proposal for Ralstonia pickettii, Ralstonia solanacearum and Ralstonia eutropha. Microbiol Immunol 39(11): 897-904.

2. Buddenhagen IW (1986) Bacterial wilt revisited. In: Persley GJ (Ed.), Bacterial Wilt Disease in Asia and the South Pacific. ACIAR Proceedings No. 13. Canberra, Australia: ACIAR, pp. 126-143.

3. Hayward AC (1991) Biology and epidemiology of bacterial wilt caused by Pseudomonas solanacearum. Annu Rev Phytopathol 29: 65-87.

4. Hayward AC (1994) The hosts of Pseudomonas solanacearum. In: Hayward AC, Hartman GL (Eds.), Bacterial Wilt: the Disease and its Causative Agent, Pseudomonas solanacearum. Wallingford, UK/Taipei, Taiwan: CABI/AVRDC, pp. 9-24.

5. Winstead NN, kelman A (1952) Inoculation techniques for evaluating resistance to Pseudomonas solanacearum. Phytopath 42(11): 628-634.

6. Kelman A (1953) The Bacterial Wilt caused by Pseudomonas solanacearum. A Literature Review and Bibliography. North Carolina Agricultural Experiment Station Technical Bulletin No. 99. Raleigh: North Carolina State University.

7. Sequeira L (1993) Bacterial wilt: past, present and future. In: Hartman GL, Hayward AC (Eds.), Bacterial Wilt. ACIAR Proceedings No. 45. Canberra, Australia: ACIAR, pp. 12-21.

8. Persley GJ (1992) Ecology of Pseudomonas solanacearum, the causal agent of bacterial wilt. Bacterial Wilt ACIAR Proc 45: 71-75.

9. Rahman MA, Hoque MO (1986) Screening of tomato varieties/lines against bacterial wilt Bangladesh. J Plant Pathology 2(1): 15-18.

10. Matsuzoe N, Okubo H, Fujieda K (1993) Resistance of tomato plants grafted on Solanum rootstocks to bacterial wilt and root-knot nematode. J Jpn Soc Hort Sci 61(4): 865-872.

11. Mochizuki H, Yamakawa K (1979) Resistance of selected eggplant cultivars and related wild Solanum species to bacterial wilt (Pseudomonas solanacearum). Bull Veg Ornam Crops Res Sta 6: 110. 
CC (9) This work is licensed under Creative Commons Attribution 4.0 License DOI: 10.19080/ARTOAJ.2019.21.556165
Your next submission with Juniper Publishers will reach you the below assets

- Quality Editorial service

- Swift Peer Review

- Reprints availability

- E-prints Service

- Manuscript Podcast for convenient understanding

- Global attainment for your research

- Manuscript accessibility in different formats ( Pdf, E-pub, Full Text, Audio)

- Unceasing customer service

Track the below URL for one-step submission https://juniperpublishers.com/online-submission.php 